Jurnal Kompetitif : Media Informasi Ekonomi Pembangunan, Manajemen dan Akuntansi Vol. 6 No. 2, September 2020

\title{
FENOMENA KEBERADAAN WARUNG TENDA JALANAN DALAM MENGGERAKKAN PEREKONOMIAN MASYARAKAT (STUDI KASUS WARUNG TENDA DIJALAN PEJANGGIK CAKRANEGARA KOTA MATARAM)
}

\author{
Rendi Oktasari ${ }^{1)}$ \\ Hery Astika Putra ${ }^{2}$ \\ Universitas Islam Al-Azhar ${ }^{1)} \&$ 2) \\ ${ }^{1)}$ Email : Rendioktasari@gmail.com \\ ${ }^{2}$ Email : heryptra@gmail.com
}

\begin{abstract}
This research is entitled "The Phenomenon of the Occasion of Street Tent Stalls in Mobilizing the Economy of the society (Study Case of Street Tent Stall on Pejanggik street, Cakranegara, Mataram)". The purpose of this research is to find out the size of the income of the people who open tent stalls on the street of the beekeepers on pejanggik street, cakranegara, Mataram, find out what things affect the income, production costs, menus produced and how to market them.

The type of research used in this study is a qualitative research with a phenomenon approach, using interviews and direct observation as a technique of the data collection, the informants of this study consisted of tent stall owners, tent stall employees, people who sell around the tent stalls and ordinary people in the pejanggik street of Cakaramegara.

The results of this study indicate that the income generated from the tent shop business is quite large on average $\mathrm{Rp}$. 9,000,000 evert month, also able to open job vacancies that can reduce unemployment. On the other hand the presence of this tent stall is able to improve the standard of living of people who sell around the tent stalls such as those selling martabak and terang bulan, cigarettes, fried foods, juices, cakes whose average income is Rp. 200,000 to Rp. 400,000 every day and able to be an attraction for the community to open the same business, especially in the culinary field.
\end{abstract}

Keywords: Income, Tent Stall, Society and Interest

\section{Pendahuluan}

Perkonomian diindonesia saat ini mengalami peningkatan yang cukup baik, disegala bidang telah banyak membawa perubahan baik dibidang investasi, bisnis, manufaktur dll. Perubahan dalam bidang ekonomi dapat merubah pola hidup masyarakat baik dipedesaan maupun diperkotaan. Pembangunan regional dibidang tronsportasi dan komunikasi berpengaruh pada volume kegiatan berbagai sektor perekonomian (industri, jasa dan perdagangan).

Kelompok usaha dapat dibedakan menjadi dua yaitu sektor formal dan informal, sektor informal merupakan hasil dari suatu proses yang panjang sektor informal yang semakin lama menjadi 
Jurnal Kompetitif : Media Informasi Ekonomi Pembangunan, Manajemen dan Akuntansi Vol. 6 No. 2, September 2020

terbalik dari ciri-ciri sektor informal itu sendiri, sebagai akibat dari sebuah proses yang cenderung membawa perubahan yang signifikan. Selanjutnya secara sederhana sektor formal dapat diartikan sebagai sektor yang sudah memiliki sifatresmi dan legal, diakui pemerintah dan bahkan mendapat pengawasan pemerintah.

Untuk mengklasifikasikan apakah pedagang warung tenda jalanan dijalan pejanggik kota mataram termasuk sektor formal atau informal, harus diteliti dan dibuktikan lebih mendalam dan nyata secara objektif. Untuk menentukan dan membuktikannya diperlukan beberapa pendekatan, pendekatan-pendekatan tesebut diantaranya: pendekatan sejarah, pendekatan sosial, pendekatan birokrasi dan pendekatan ekonomi.

Peneliti diindonesia telah menghasilkan 8 ciri pokok sektor informal yang bersifat kualitatif (Hidayat, 2000) ${ }^{1}$. (1) umumnya kegiatan usahanya tidak memiliki izin usaha, (2) pola kegiatannya tidak teratur, (3) kegiatan usahanya tidak terorganisir dengan baik, (4) umumnya kebijakan pemerintah untuk membantugolongan ekonomi yang lemah, (5) modal dan perputaran usaha relative kecil, (6) unit usahanya mudah keluar masuk dari satu sub sektor ke sub sektor yang lain, (7) teknologi yang digunakan sederhana, (8) umumnya unit usaha termasuk golongan One Man Enterprise dan jika memperkerjakan buruh bersal dari keluarga atau tetangga.

Pedagang warung tenda jalanan dijalan pejanggik kota mataram, jika dilihat dari pengertian dari sektor formal dan sektor informal, maka pedagang tersebut dapat dikatakan sebagai suatu usaha yang bergerak pada sektor informal, karena sebagian besar ciri-ciri yang terdapat pada sektor informal sesuai denga pandangan peneliti, dapat dipenuhi oleh pedagang warung tenda jalanan dijalan pejanggik kota mataram,. Hal ini dapat dilihat dari jenis dagangan yang dijual tidak ditemukan adanya pedagang yang menggunakan teknologi, mendapatkan proteksi dan bantuan dari pemerintah.

Para pedagang makanan yang menggunakan tenda sebagai media untuk menjalankan usahanya dapat dikategorikan seperti penjual lalapan, pecel lele, nasi goreng atau nasi goreng seafood dan ayam taliwang. Mereka yang menggunakan tenda sebagai media usahanya meletakkan barang dagangannya didalam rombong. Dikota mataram sudah banyak kita jumpai disepanjang jalan terutama didaerah-daerah yang menjadi pusat kota atau disuatu tempat dimana didaerah tersebut ramai dikunjungin oleh masyarakat, terutama dijalan pejanggik-cakranegara kota mataram. Maka

\footnotetext{
${ }^{1}$ Hidayat. 2000. Pengembangan Sektor Formal Dan Informal. Bandung: Universitas Padjajaran.
} 
Jurnal Kompetitif : Media Informasi Ekonomi Pembangunan, Manajemen dan Akuntansi Vol. 6 No. 2, September 2020

dapat pula kita jumpai pedagang yang berjualan menggunakan tenda tersebut. Para pedagang yang menggunakan tenda sebagai media usahanya kerap menyebut usaha mereka dengan sebutan "Warung Tenda Jalanan".

Fenomena pedagang yang menggunakan tenda nampaknya baru terlihat dalam kurun waktu 15 tahun belakangan ini, namun baru tahun 2014 sampai sekarang yang terlihat semakin banyak pedagang yang memanfaatkan tenda untuk berdagang bahkan mereka berlomba-lomba menggunakan tenda yang kreatif dalam berdagang, para pedagang bukan hanya dari kalangan yang tua saja, bahkan banyak kalangan anak muda yang berdagang dengan menggunakan tenda, dikarenakan semakin meningkatnya permintaan konsumen.

Ditinjau dari sisi positifnya keberadaan warung tenda jalanan ini mampu menyerap tenaga kerja dan mampu memperbaiki perekonomian pedagang maupun karyawan warumg tenda tersebut. Kehadiran warung tenda mampu mempermudah masyarakat yang sibuk kerja mencari makan sesuai yang mereka butuhkan disaat malam hari, sehingga mereka mendapatkan pelayanan yang mudah untuk mendapatkan makanan yang mereka butuhkan.karena kebanyakan masyarakat modern sekarang malas untuk masak dirumah, mereka mencari makanan yang sudah jadi, karena kesibukan mereka kerja dari pagi sampai sore bahkan ada yang kerja sampai malam hari. Itu sebabnya mereka membeli makanan yang sudah jadi.

Berdasarkan uraian latar belakang diatas maka peneliti tertarik dengan judul "Fenomena Keberadaan Warung Tenda Jalanan Dalam Mengerakkan Perekonomian Masyarakat (Studi Kasus Warung Tenda Dijalan Pejanggik-Cakranegara Kota Mataram NTB) dengan rumusan masalah dalam penelitian ini adalah bagaimana Keberadaan Warung Tenda Jalanan Dalam Mengerakkan Perekonomian Masyarakat. Tujuan penelitian ini adalah untuk mengetahui keberadaan warung tenda jalanan dalam mengerakkan perekonomian masyarakat.

\section{Landasan Teori}

\section{Fenomena}

Fenomena adalah gejala atau suatu hal yang timbul yang bisa jadi daya magnet (ketertarikan) untuk diteliti. Fenomena adalah suatu hal yang bisa disaksikan dengan panca indra serta dapat dinilai dan diterangkan secara ilmiah. Dari pengertian diatas dapat disimpulkan bahwa fenomena adalah berbagai hal yang dapat disaksikan dengan panca indra serta dapat juga disebut suatu gejala. 
Jurnal Kompetitif : Media Informasi Ekonomi Pembangunan, Manajemen dan Akuntansi Vol. 6 No. 2, September 2020

\section{Warung}

Warung adalah usaha kecil yang dimiliki oleh keluarga yang berbentuk kedai, kios, toko kecil dan restoran sederhana. Istilah warung dapat ditemukan diindonesia dan Malaysia, warung adalah salah satu bagian penting dalam kehidupan keseharian rakyat Indonesia. Terdapat banyak jenis warung pada umumnya bebentuk toko kecil seperti gerobak dorong beratap yang menjual rokok, minuman, makanan, permen dan berbagai macam barang-barang untuk keperluan seharihari.

\section{Tenda}

Tenda adalah tempat pelindung yang terdiri dari lembaran kain atau bahan lainnya yang menutupi, yang melekat pada kerangka tiang atau menempel pada tali pendukung, beberapa tenda tidak perlu berdiri diatas tanah karena ada beberapa model tenda yang menggantung dipohon.

\section{Jalan}

Jalan adalah prasarana transportasi darat yang meliputi segala bagian jalan, termasuk bangunan pelengkap dan perlengkapannya yang diperuntukkan bagi lalu lintas, yang berada pada permukaan tanah, di atas permukaan tanah, di bawah permukaan tanah dan/atau air, serta di atas permukaan air, kecuali jalan kereta api, jalan lori, dan jalan kabel. Jalan umum adalah jalan yang diperuntukkan bagi lalu lintas umum. Jalan khusus adalah jalan yang di bangun oleh instasi, badan usaha, perseorangan, atau kelompok masyarakat untuk kepentingan sendiri. Jalan tol adalah jalan umum yang merupakan bagian sistem jaringan jalan dan sebagai jalan nasional yang penggunanya diwajibkan membayar tol.

\section{Teori Ekonomi}

Menurut J.L. Meij (Abdullah, 1992: 6) ${ }^{2}$ mengemukakan bahwa ilmu ekonomi adalah ilmu tentang usaha manusia ke arah kemakmuran. Pendapat tersebut sangat realistis, karena ditinjau dari aspek ekonomi di mana manusia sebagai mahluk ekonomi (Homo Economicus) pada hakekatnya mengarah kepada pencapaian kemakmuran. Kemakmuran menjadi tujuan sentral dalam kehidupan manusia secara ekonomi, sesuai yang dituliskan pelopor "liberalisme ekonomi" oleh Adam Smith dalam buku "An Inquiry into the Nature and Cause of the Wealth of Nations" tahun 1976.

\footnotetext{
${ }^{2}$ Abdullah. 1992. Materi Pokok Pendidikan. Jakarta: Departemen Pendidikan dan Kebudayaan, PPPG Tertulis.
} 
Jurnal Kompetitif : Media Informasi Ekonomi Pembangunan, Manajemen dan Akuntansi Vol. 6 No. 2, September 2020

\section{Teori Pertumbuhan Ekonomi}

Menurut Simon Kuznets (1971) dalam Jhingan (2000) ${ }^{3}$, mendefinisikan pertumbuhan ekonomi sebagai "kenaikan jangka panjang dalam kemampuan suatu Negara untuk menyediakan semakin banyak jenis barang-barang ekonomi kepada penduduknya. Kemampuan ini tumbuh sesuai dengan kemajuan teknologi, dan penyesuaian kelembagaan dan idiologis yang diperlukan. Definisi ini mempunyai 3 komponen: pertama, petumbuhan ekonomi suatu bangsa terlihatdari meningkatnya secara terus-menerus persediaan barang; kedua, teknologi merupakan faktor dalam pertumbuhan ekonomi yang menentukan derajat pertumbuhan kemampuan dalam penyediaan aneka macam barang kepada penduduk; ketiga, penggunaan teknologi secara luas efisien memerlukan adanya penyesuaian dibidang kelembagaan dan idiologi sehingga inovasi yang dihasilkan oleh ilmu pengetahuan umat manusia dapat dimanfaatkan secara tepat.

\section{Pendapatan.}

Secara umum pendapatan adalah sejumlah uang yang di terima anggota masyarakat sebagai balas jasa yang bergubungan dengan produksi barang dan jasa. Selanjutnya secara lebih sfesifik pendapatan atau income dari setiap warga masyarakat adalah hasil penjualannya dari setiap faktor-faktor produksi. Harga faktor produksi di pasar produksi (seperti halnya juga untuk barang-arang di pasar barang) di tentukan oleh tarik menarik antara penawaran dan permintaan (Boediono, 1990:92) ${ }^{4}$.

\section{Metode Penelitian}

Penelitian ini menggunakan metode kualitatif pendekatan fenomena. Pada penelitian ini yang menjadi informan adalah orang-orang yang mempunyai kaitan erat dengan pedagang warung tenda jalanan dijalan pejanggik. Mereka yang menjadi informan dalam penelitian adalah pemilik warung tenda dan para karyawandan masyarakat sekitar pembeli (konsumen). Peneliti pun memilih 15 orang sebagai informasi pendukung sehingga menjadi 15 informan penelitian, 10 orang informan utama dan 5 orang informan tambahan. Pengumpulan data dilakukan pada natural setting ( kondisi yang alamiah) dan sumber data primer. Teknik pengumpulan data dalam penelitian ini dengan cara observasi, wawancara dan dokumentasi.

\section{Hasil Penelitian Dan Pembahasan}

\section{Modal dan Penetapan Harga Jual}

\footnotetext{
3 Jhingan, 2000. “Ekonomi Pembangunan dan Perencanaan”. Jakarta : Rajawali Press.

${ }^{4}$ Boediono, 1999. Teori Pertumbuhan Ekonomi. BPFE, Universitas Gajah Mada Yogyakarta.
} 
Jurnal Kompetitif : Media Informasi Ekonomi Pembangunan, Manajemen dan Akuntansi Vol. 6 No. 2, September 2020

Hasil wawancara dapat disimpulkan bahwa penjualan warung tenda jalanan dijalan pejanggik, cakranegara kota mataram menu dan harga nya hampir sama, tidak terlalu jauh perbedaannya dan tingkat keramaian pengunjung dan pembeli setaiap hari nya juga hampir sama karena setiap warung tenda sudah mempunyai pelanggan tersendiri hanya yang membedakan hari-hai penting tertentu, yang seperti saya jelaskan diatas.

Sedangkan untuk promosi sendiri setiap warung tenda hanya menggunakkan facebook, instagram, whatshapp dan yang paling berpengaruh adalah penyampai dari mulut ke mulut oleh pelanggan atau pembeli yang sudah menjadi langganan diwarung tenda tersebut, mereka membawa teman, keluarga, teman kantor dan teman diluar daerah untuk makan diwarung tenda tersebut, hal seperti ini sangat berpengaruh untuk keramaian warung tenda tersebut. Dan juga dapat disimpulkan bahwa semakin naik harga pokok yang dijual sepeti ayam, ikan, cabe, tomat, bawang pitih/merah dan bumbuan lainnya, maka harga jual juga semakain naik.

\section{Biaya Produksi Warung Tenda}

Seperti yang dikatakan Bapak Heri yang merupakan pemilik salah satu warung tenda mengatakan:

"Biaya awal pembuatan/pembelian rombong atau gerobak, tenda, kompor gas, wajan/penggorengan, meja + kursi, spanduk dan peralatan lainnya. Kira-kira seharga Rp. 4.000.000-5.000.000an. sedangkan harga bahan pokok atau menu tergantung dari harga bahan pokok dipasar kalau harga bahan pokok naik harga jual juga naik."

Hasil wawancara saya dengan mas anto suherman dia mengatakan bahwa:

"Biaya awal pembuatan/pembelian rombong atau gerobak, tenda, kompor gas, wajan/penggorengan, meja + kursi, spanduk dan peralatan lainnya. Kira-kira seharga Rp. 4.500.000-5.500.000an. hampir sama biaya nya sama pak heri, yang membedakan beliau lebih banyak kursi sama meja. sedangkan harga bahan pokok atau menu, beliau juga mengatakan hal yang sama dengan pemilik warung tenda lain."

Hasil Wawancara saya dengan salah satu karyawan warung tenda ayam taliwang sejahtera, mas Badrus dia mengatakan bahwa:

"Biaya awal pembuatan/pembelian rombong atau gerobak, tenda, kompor gas, wajan/penggorengan, meja + kursi, spanduk dan peralatan lainnya. Dulu Kira-kira seharga Rp. 6.000.000-7.000.000an. sedangkan harga bahan pokok atau menu, dia juga mengatakan tergantung dari harga bahan pokok dipasar kalau harga bahan pokok naik harga jual juga naik."

Dari hasil wawancara diatas dapat disimpulkan bahwa modal yang besar itu modal awalnya sedangkan harga jual tergantung dari harga pokok yang dujual dipasar, jka harga bahan pokok naik maka harga jual juga naik. 
Jurnal Kompetitif : Media Informasi Ekonomi Pembangunan, Manajemen dan Akuntansi

Vol. 6 No. 2, September 2020

\section{Peralatan Produksi}

Berdasarkan hasil wawancara yang saya lakukan dengan para pemilik dan pekerja warung tenda jalanan dijalan pejanggik cakranegara kota mataram pada umum nya semua sama seperti rombong atau gerobak, tenda, kompor gas, wajan/penggorengan, meja dan kursi, spanduk dan peralatan lainnya. Hanya yang membedakkan ayam taliwang meraka memiliki pembakaran untuk menu yang akan dibakar.

\section{Strategi Pemasaran Dan Tingkat Pendapatan}

Berdasarkan hasil wawancara yang saya lakukan dengan para pemilik Warung Tenda mengenai pemasaran warung tenda jalanan tidak banyak tidak ada hal spesial yang dilakukan hanya saja dengan berkembangnya media sosial di era globalisasi yang semakin maju banyak muncul berbagai inovasi pemasaran baru yang memberikan kemudahan dalam memperkenalkan hasil produk/menu kepada calon pelanggan dengan cara memasang photo atau gambar produk yang dihasilkan melalui media sosial seperti facebook, whatsapp, website. Disisi lain pemasaran juga dilakukan secara tradisional yaitu dari yang seperti dari mulut kemulut pelanggan yang sudah lama. Seperti yang dikatakkan oleh bapak heri:

"beliua mengatakan cara promosi tidak banyak yang beliau lakukan seperti pedagang warung tenda lainnya, hanya pelanggan warungnya nya saja yang memperkenalkan dari mulut kemulut dan beliau juga mengatakan kata dia tidak perlu promosi lewat sosmed karna menurut beliau, rezeki sudah diatur, mereka akan dtang sendiri, yang penting kita jalanin dengan niat dan berdagang denagan sehat."

Hasil wawancara saya dengan mas asroni muslim yaitu

"Sekarang kan sudah ada internet yang digunakan untuk promosi-promosi dagangan, tidak seperti dulu agak susah, sudah tidak bingung lagi seperti dulu"

Hasil wawancara saya dengan mas sulton salah satu karyawan warungtenda taliwang sehatera

"Beliau mengatakan tidak banyak yang dilakukan oleh bosnya untuk promosi karena menurutnya bosnya sudah punya pelanggan tetap dari dulu, dan beliau juga mengatakkan dulu sempat daftar di Gojek atau Grab tapi sekarang sudah berhenti, tapi beliau juga menambahkan hanya pemesahan ojek-ojek biasa juga ada beberapa pelanggan."

Hasil wawancara saya dengan bapak mamik yusuf, dia mengatakan bahwa

"Memang sekarang zaman sudah cangging, jadi beliau juga sempat promosi lewat facebook, instagram wa dan media internet lainnya, tapi beliau mengatakkan juga beliau juga punya pelanggan tetap sekarang, dan banyak juga kenalan beliau dari luar daerah sering makan ditempat beliau dengan membawak teman-temannya. Dan beliau juga sempat ditawarin oleh teman beliau untuk membuka cabang diluar daerah tapi, mereka beliau belum tertarik"

Hasil wawancara saya dengan bapak joko suherman, dia mengatakan bahwa

"Dia mengatakan bahwa beliau juga sudah mempunyai pelaggan tetap sama seperti pedagang lainnya. Jadi dari mulut kemulut sajalah, tuturnya dia. Emang dia juga sempat promosi lewat medsos seperti facebok, instagram, WA dan sempat juga daftar di Grab atau Gojek tap sekarang sudah berhenti." 
Jurnal Kompetitif : Media Informasi Ekonomi Pembangunan, Manajemen dan Akuntansi

Vol. 6 No. 2, September 2020

Dari hasil wawancara diatas dapat disimpulkan bahwa dari semua stategi pemasaran yang dilakukan, yang dapat mendatang pelanggan atau pembeli yaitu dari pelanggan atau pembeli lama dari mulut kemulut dan ada sedikit pengaruh dari media sosial.

\section{Peningkatan Pendapatan Masyarakat Yang Berjualan Disekitaran Jalan Pejanggik Dengan Adanya Warung Tenda}

Keberadaan warung tenda ini bisa mengurai pengangguran karena karyawan yang di pekerjakan tidak membutuhkan pendidikan tinggi tidak tamat SD pun boleh asalkan dia mempunyai kemauan dan mau bekerja keras. Disisi lain banyak bapak-bapak atau ibu-ibu yang membuat rombong-rombong kecil untuk menjual rokok, kopi, kue, ada juga penjual terang bulan dan mertabak, juga ada juga yang menjual jenis minum-minuman seperti jus. sehingga karyawan dan pemilik warung tenda atau masyarakat yang belanja diwarung tenda juga ada yang belanja diwarung tersebut untuk menghasilkan pendapatan. Selain itu, tingkat perekonomian juga bisa dilihat jenis pekerjaan yang digeluti oleh anggota kepala keluarga baik itu pedagang warung tenda, pedagang lainnya, guru, pengusaha, karyawan swasta, tukang ojek itu pun ada yang memiliki kerjaan sampingan.

Hasil wawancara menunjukkan masyarakat yang berjualan sekitaran warung tenda mengungkapkan bahwa tingkat pendidikan tidak menjadi penentu dalam melakukan usaha berjualan dengan menggunakan tenda ini, banyak juga masyarakat yang berjualan disekitaran warung tenda dijalan pejanggik mendapatkan keuntungan yang cukup dengan adanya warung tenda ini.

\section{Rata-Rata Pendapatan}

Rata-rata pendapatan yang didapatkan oleh pedagang warung tenda sebagai berikut:

Tabel 1. Rata-Rata Pendapatan

\begin{tabular}{|l|l|l|}
\hline Nama warung tenda & Menu yang paling laku & $\begin{array}{l}\text { Rata-rata } \\
\text { pendapatan } \\
\text { perbulan }\end{array}$ \\
\hline Lalapan bu heri & Ayam Lalapan & Rp. 7.800.000 \\
\hline Nasgor seafood & Nasgor biasa & Rp. 9.750.000 \\
\hline Lalapan bumbu ijo & Nasi Ayam & Rp. 8.120.000 \\
\hline Ayam taliwang la-Hap & Ayam & Rp. 7.840.000 \\
\hline Ayam Taliwang Putri Duyung & Ayam & Rp. 8.540.000 \\
\hline Ayam taliwang sejahtera & Ayam & Rp.11.900.000 \\
\hline Ayam taliwang sejati & Ayam & Rp. 6.040.000 \\
\hline Pecel lele dinasty & Ayam dan ikan lele & Rp. 8.910.000 \\
\hline Ayam taliwang mandiri & Ayam & Rp. 9.000.000 \\
\hline Pecel lele muslim & Ayam & Rp.10.800.000 \\
\hline
\end{tabular}


Jurnal Kompetitif : Media Informasi Ekonomi Pembangunan, Manajemen dan Akuntansi Vol. 6 No. 2, September 2020

Dari tabel di atas dapat disimpulkan bahwa rata-rata penghasilan warung tenda $\mathrm{Rp}$. 9.000.000 perbulan dan menu yang paling banyak di diminati/terjual adalah ayam.

\section{Keadaan Sosial Ekonomi Masyarakat Dan Pemilik Warung Tenda Yang Berjualan Dijalan}

\section{Pejanggik}

untuk mengetahui keadaan sosial ekonomi masyarakat yang berjualan menggunakan tenda/warung tenda kalau dilihat dari kehidupan sehari-harinya yang tergambar dari tempat tinggal yang mereka miliki rata-rata bagus atau layak huni, dengan usaha yang ditekuni. Dari hasil pengamatan dan wawancara saya dengan beberapa pemiliki warung tenda, taraf hidup masyarakat usaha warung tenda cukup baik dan menjanjikan, dapat dilihat dari beberapa rumah pemilik warung tenda yang cukup bagus dam mampu membiayai anak sekolah sampai keperguruan tinggi, rata-rata memiliki kendaraan roda dua dan ada beberapa pemilik warung tenda yang memiliki kendaraan roda empat, bahkan ada yang sampai bisa pergi umroh, bahkan ada yang bisa naik haji dan juga ada yang bisa membawa orang tuanya pergi haji juga.

\section{Kelemahan, Kekuatan, Peluang Dan Ancaman Warung Tenda Jalanan}

Kelemahan yang dimiliki oleh pengusaha warung tenda yaitu kurang nya perhatian dari pemerintah baik. Kekuatan yang dimiliki oleh pengusaha warung tenda ini yaitu mampu berdiri sendiri tanpa ikut campur tangan pemerintah. Peluang yang dimiliki oleh pengusaha warung tenda ini sangat menjanjikan untuk perekonomian pengusaha itu sendiri, dan mampu menjadi penarik minat melenial untuk belajar usaha mandiri. Ancaman yang dimilki oleh pengusaha warung tenda ini dengan munculnya pengusaha warung tenda yang baru, yang leih laku dan mempunyai pariasi baru yang membuat kecemburuan atau keirian karena satu warung yang cukup rame yang diminati oleh pembeli. Dan yang paling menjadi ancaman ketika ada perbaikan jalan atau trotoar, otomatis mereka tidak bisa bejualan.

\section{Fenomena Keberadaan Warung Tenda Jalanan Dalam Menggerakkan Perekonomian Masyarakat \\ Minat Masyarakat untuk Berwirausaha dibidang Kuliner}

Menurut hasil wawancara saya dengan beberapa masyarakat dijalan pejangggik atau masyarakt sekitarnya tentang minat mereka untuk berwira usaha di bidang kuliner, salah satunya adalah bapak nasrudin beliau mengatakan:

"minat saya sudah pasti ada, apalagi kalau saya lihat masyarakat yang berjualan kuliner hasilnya banyak yang menjanjikan, tapi yang menjadi gejala saya modal, ini aja saya berjualan rokok dll modalnya pas-pasan"

Hasil wawancara saya dengan mas badrus dia mengatakan:

"saya juga minatnya besar untuk mecoba berjualan atau membuka usaha sendiri seperti warung tenda dll, tapi sekarang saya harus banyak belajar dulu sekarang, ya seperti jadi 
Jurnal Kompetitif : Media Informasi Ekonomi Pembangunan, Manajemen dan Akuntansi

Vol. 6 No. 2, September 2020

karywan seperti ini, kita harus banyak belajar dulu dan yang menjadi gejala utama juga dimodal, kita kan hanya masyarakat menengah kebawah jadi kita butuh masukkan modal untuk membuka usaha baru"

Hasil wawancara saya dengan mas ali dia mengatakan:

"suatu saat saya pasti akan membuka usaha kuliner, karena saya sangat tertarik untuk berwira usaha dibidang kuliner, ya karena saya orang nya lumayan suka kuliner, ya saya berharap ada bantuan dari pemerintah kedapa anak muda seperti kita ini, baik itu pelatihan atau modal"

Hasil wawancara saya dengan iman dia mengatakan:

"saya tertarik untuk berwira usaha didang kuliner seperti mereka, ya tap saya tidak ada skill untuk bisa bikin masakan dibidang kuliner dan saya sngat berharap pemerintah lebih memperhatikan lagi masyarakat yang berminat untuk berwira usaha"

Hasil wawancara saya dengan ibu sri dia mengatakan:

"saya sangat berminat mas untuk berwira usaha dibidang kuliner dan saya berminat untuk membuka cabang lagi untuk berjualan gorengan, atau usaha yang lebh besar lagi, ya seperti usaha warung tenda, ya tapi itu dah mas, gejala utama saya dimodal dan saya berharap ada bantu dari pemerintahbuntuk memberi modal baik dari segi materi, peralatan dan pelatihan"

Dan disini juga peneliti melakukan wawancara dengan beberapa pengunjung warung tenda. Hasil wawancara saya dengan bapak serdik dia mengatakan:

"saya meresa sangat puas dengan pelayanan yang diberikan oleh pemilik atau karyawan dan juga saya saat merasa sangat terbantu dengan adanya keradaan warung tenda ini. Kan dirumah istri jarang masak, karena punya anak kecil, jadi saya beli aja makanan diwarung tenda"

Jadi, dari hasil wawancara diatas dapat disimpulkan bahwa minat masyarakat untuk membuka usaha atau berwira usaha dibidang kuliner sangat besar. Tapi yang kebanyakan yang menjadi gejala atau kendala utama meraka yaitu modal utama untuk memulai membuka usaha. Dapat juga disimpulkan dari hasil wawancara dengan beberapa pengunjung warung tenda bahwa mereka sangat terbantu dengan adanya keberadaan warung tenda jalanan dan mereka mengatakkan puas dengan pelayanan yang diberikan.

\section{Warung tenda Sebagai Lahan Baru Untuk Mengembangkan Usaha}

Kalau dilihat dari beberapa wawancara dengan masyarakat diatas, sudah sangat jelas usaha warung tenda sangat bagus untuk dikembang kan dan jalankan atau di ikuti oleh masyarakat lainnya, selain hasilnya yang sangat menjanjikan dan mampu membuka lowongan pekerjaan bagi masyarakat yang tidak mempunyai skil juga masyarakat yang pendidikkan nya rendah. Dari hasil penjualan warung tenda banyak masyarakat perekonomiaannya membaik dan mampu menyekolahkan anak sampai keperguruan tinggi. 
Jurnal Kompetitif : Media Informasi Ekonomi Pembangunan, Manajemen dan Akuntansi

Vol. 6 No. 2, September 2020

\section{KESIMPULAN DAN SARAN \\ Kesimpulan}

Usaha warung tenda ini termasuk usaha mikro yang sangat menjanjikan, memiliki peluang yang sangat luas untuk usaha, yang berdampak pada pendapatan masyarakat sekitar, karyawan dan terutama pendapatan pemilik warung tenda itu sendiri. Hal ini, berdasarkan pengamatan dari usaha warung tenda yaitu:

1. Pendapatan cukup besar rata-rata Rp. 9.000 .000 perbulan

2. Dapat sedikit mengurangi pengangguran karena karyawan yang berkerja diwarung tenda pekerja keras sampai larut malam dan mau belajar sehingga mereka memiliki keahlian suatu saat dapat membuka jenis usaha yang sama atau buka usaha lainnya.

3. Dan sisi lain dengan keberadaan warung tenda ini mampu meningkatkan taraf hidup masyarakat yang berjualan juga disekitaran warung tenda seperti warung kopi, rokok, kue martabak/terang bulan dan gorengan tyang rata-rata penghasilan Rp. 200.000 sampai Rp. 400.000 perhari bhkan ada sala satu penjual kue sehari bisa dapat rp. 1.000 .000 sampai Rp. 2.000.0000 perhari.

Pendapatan warung tenda tergantung hari, kalau hari-hari biasa normal pemasukannya karena setiap warung tenda sudah memiliki pelanggan tetap. Jadi yang menjadi penentu yaitu ketika memasuki bulan puasa sampai lebaran topat, hari nyepi, tahun baru dan ketika ada ada acara besar yang sedang berlangsung dikota mataram seperti yang terjadi ditahun sebelumnya yaitu MTQ di Islamic Center, pendapatan pedagang warung tenda meningkat drastis. Dan semua menu laku, menu yang paling laku ayam, baik itu ayam lalapan maupun ayam taliwang. Besar kecilnya pendapatan dapat dilihat dari pertumbuhan ekonomi dan keadaan sosialnya seperti tingkat pendidikan, jenis pekerjaan yang dimiliki dan keadaan kehidupannya sedangkan keadaan sosialnya bisa dilihat dari bentuk fisik yang dimiliki, harta benda dan tempat tinggal.

Dan usaha warung tenda ini mampu menarik minat masyarakat untuk membuka usaha atau berwira usaha dibidang kuliner sangat besar. Karen hasilnya sangat menjanjikan, tapi yang menjadi gejala atau kendala utama meraka untuk memulai usaha yaitu modal.

\section{Saran}

1. Untuk pengusaha warung tenda cobalah untuk membuat daya tarik terbaru seperti menu yang berbeda atau memiliki ciri khas tersendiri daripada warung tenda yang lain, cobalah untuk promosi yang lebih disemua medsos, untuk menjadi daya tarik peminat/pecinta 
Jurnal Kompetitif : Media Informasi Ekonomi Pembangunan, Manajemen dan Akuntansi Vol. 6 No. 2, September 2020

kuliner yang ada diluar kota maupun diluar daerah, supaya mereka tau tempat yang bida dikunjungin ketika datang liburan kelombok terutama kota mataram, dan berani untuk membuka cabanng yang baru, dibeberapa tempat bahkan kalau bisa diluar kota atau diluar daerah.

2. Untuk pemerintah juga diharapkan dapat berkontribusi membantu masyarakat yang membuka usaha warung tenda atau masyarakat yang ingin membuka usaha baru dibidang kuliner dengan memberi bantuan pelatihan maupun bantuan berupa materi bagi pengusaha pemula. Karena usaha mikro seperti ini sangat menjanjikan.

3. Untuk pemilik warung tenda dan masyarakat jika kekurangan modal untuk membuka usaha baru lebih baik membuntuk kelompok usaha untuk mengajukkkan dana kurs di bank, sekarang sudah ada bank yang menyediakan dana untuk usaha salah satunya bank btpn syariah.

4. Untuk peneliti yang akan datang jika membahas atau mengangkat judul penelitan yang sama agar judul lebih dikembangkan lagi, fokus permasalahan lebih diperluas dan lebih baik lagi.

\section{DAFTAR PUSTAKA}

Abas Kartadinata. 2001. Akutansi dan Analisis Biaya.: Aneka Cipta. Jakarta.

Abdullah. 1992. Materi Pokok Pendidikan. Jakarta: Departemen Pendidikan dan Kebudayaan, PPPG Tertulis.

Adisasmita, Raharjo, 2013. Teori- Teori Pembangunan Ekonomi. Yogyakarta: Graha Ilmu

Ahman, Eeng. 2007. Membina Kopetensi Ekonomi Untuk Kelas X SMA/MA. Bandung: Grafindo Media Pratama.

Arsyad, Lincolin. 1999. Pengantar Perancanaan dan Pengembangan Ekonomi Daerah.: BPFE. Yogyakarta.

Boediono, 1999. Teori Pertumbuhan Ekonomi. BPFE, Universitas Gajah Mada Yogyakarta. Drs. Robinson Tarigan. 2003. Ekonomi Regional. Teori Dan Aplikasi.

Freddy Rangkuti. 2008. Analisis SWOT Teknik Membedah Kasus Bisnis. Gramedia Pustaka Utama. Jakarta

Hansen dan Mowen, 2004. Manajemen Biaya , Edisi Bahasa Indonesia. Buku Kedua.: Salemba Empat. Jakarta

Hidayat. 2000. Pengembangan Sektor Formal Dan Informal. Bandung: Universitas Padjajaran

Ida Nuraini. 2016. Pengantar Ekonomi Mikro. Universitas Muhammadiyah Malang Jayadinata. .J.T. 1999. Tata Guna Tanah Dalam Perencanaan Pedesaan, Perkotaan Dan Wilayah. Bandung. ITB.

Jhingan, 2000. “Ekonomi Pembangunan dan Perencanaan”. Jakarta : Rajawali Press

Dessy Purti Andini. 2013. Studi Kelayakan Usaha Warabala Warung Pangestu Dikabupaten Jember. Politeknik Negeri Jember. 
Jurnal Kompetitif : Media Informasi Ekonomi Pembangunan, Manajemen dan Akuntansi

Vol. 6 No. 2, September 2020

Farin Karisma. Dkk. 2015. Kiat Pemasaran Usaha Pecel Lele Diwarung Tenda Sepanjang Jalan Lintas Timur Sumatera Kecamatan Lirik Kabupaten Indragiri Hulu Provinsi Riau. Universitas Riau.

Nurvina Prasdika. 2017. Potret Fenomena Kehidupan Pedagang Kaki Lima Dipasar Bumbuh Kuning Bandar Lampung, Universitas Lampung.

Kasto. 2000. “Konsep Dan Pengukuran Ketenagakerjaan”. Disampaikan Pada Pelatihan Mobilitas Penduduk. Yogyakarta: Pusat Pelatihan Kependudukan. Universitas Gadjah Mada.

Kibrandoko. 2011. Pengantar Mikro Ekonomi. Jakarta: PT. Gelora Aksara P.

Latri. Wihastuti. 2008. Pertumbuhan Perekonomian Indonesia. Universitas Muhammadiyah. Yogyakarta.

M Nafirin, 2009. Penganggaran perusahaan. Edisi 3. Salemba Empat. Jakarta

M. Suparmoko. 1999. Metode Penelitian Praktis. Bpfe Yogyakarta.

Mahmudi. 2006. Analisis Laporan Keuangan. Yogyakarta. UPP AMP YKPN.

Michael. P. 2000. Pembangunan Ekonomi Didunia Ketiga. Erlangga. Jakarta Vas Press.

Moleong L.J. 2011. Metodelogi Penelitian Kualitatif Edisi Revisi. PT. Remaja Rosdakarya. Bandung.

Mulyadi, 2009. Akuntansi Biaya. STIE YPKPN. Yogyakarta

Patton. MQ. 2009. Metode Evaluasi Kualitatif. Pustaka Belajar. Jakarta.

Payaman J Simanjuntak. 1999. Pengantar Ekonomi Sumber Daya Manusia. Penerbit. FE UI Jakarta.

Slameton. 2010. Belajar dan Faktor-faktor yang mempengaruhinya. Jakarta. PT. Rineka Cipta.

Sadono, Sukirno. 1997. Pengantar Teori Makro Ekonomi. Edisi 2. Raja Grafindo Persada.: Jakarta

Sadono, Sukirno, 2002. Teori Mikro Ekonomi.. Cetakan Keempat Belas. Rajawali Prees. Jakarata

Sadono, Sukirno, 2006. Ekonomi Pembangunan proses masalah dan dasar kebijakan.: Rajawali Prees. Jakarata

Sarosa, Samiaji, 2012. Penelitian Kualitatif Dasar-dasar, Indeks. Jakarta

Soekarwati, 2003. Teori Ekonomi Produksi Dengan Pokok Bahasa Analisis Fungsi Cob Dougls.: Kencana. Jakarta

Soemita, 2002. Budget Perusahaan. Penerbit Sinar Baru.

Soedarsono, 1982. Pengantar Ekonomi.: LP3ES. Yogyakarta

Sugiono, 2010. Metode Penelitian Pendidikan Pendekatan Kuantitatif, kualitatif dan R\&D. ALFABETA. Bandung

Sugiono. 2013. Metodelogi Penelitian Pendekatan Kuntitatif Dan Kualitatif Dan R\&D. ALFABETA. Bandung

Sutrisno, Hadi, 1997. Metode Penelitian.: UGM Press. Yogyakarta

Winardi. 2002. Pengantar Ilmu Ekonomi. Cetakan Ketujuh. Bandung Tarsito.

Yunus Aulia Insane. 2011. Potret Kehidupan Sosial Ekonomi Pedagang Kaki Lima Dikota Makassar. Universitas Hasanudin. 